\title{
Injuries resulted from breastfeeding: a new approach to a known problem*
}

\author{
LESÕES MAMILARES DECORRENTES DA AMAMENTAÇÃO: UM NOVO OLHAR PARA \\ UM CONHECIDO PROBLEMA
}

\section{LAS GRIETAS DEL PEZÓN SECUNDARIAS DE LA LACTANCIA MATERNA: UNA NUEVA MIRADA A UN CONOCIDO PROBLEMA}

\author{
Marina Possato Cervellini' ${ }^{1}$, Mônica Antar Gamba², Kelly Pereira Coca ${ }^{3}$, Ana Cristina Freitas de \\ Vilhena Abrão ${ }^{4}$
}

\begin{abstract}
This study aimed at analyzing nipple trauma resulted from breastfeeding based on dermatological approach. Two integrative reviews of literature were conducted, the first related to definitions, classification and evaluation methods of nipple trauma and another about validation studies related to this theme. In the first part were included 20 studies and only one third defined nipple trauma, more than half did not defined the nipple's injuries reported, and each author showed a particular way to assess the injuries, without consensus. In the second integrative review, no validation study or algorithm related to nipple trauma resulted from breastfeeding was found. This fact demonstrated that the nipple's injuries mentioned in the first review did not go through validation studies, justifying the lack of consensus identified as far as definition, classification and assessment methods of nipple trauma.
\end{abstract}

\section{RESUMO}

Este estudo teve como objetivo analisar o trauma mamilar decorrente da prática da amamentação sob o enfoque dermatológico. Duas revisões integrativas da literatura foram realizadas, uma relacionada a definições, classificações e método de avaliação dos traumas mamilares e outra sobre estudos de validação relacionados a essas temáticas. Na primeira foram incluídos 20 artigos e apenas um terço conceituou o trauma mamilar, mais da metade não definiu as lesões mamilares relatadas e cada autor demonstrou uma forma particular de avaliação das lesões, sem que houvesse consenso. Na segunda, nenhum estudo de validação ou algoritmo relacionado ao trauma mamilar decorrente da amamentação foi encontrado. Este achado demonstrou que as lesões citadas na primeira revisão não passaram por estudos de validação com especialistas, o que explica as discordâncias identificadas em relação à definição, classificação e métodos de avaliação dos traumas mamilares.

\section{DESCRITORES}

Aleitamento materno

Mamilos

Ferimentos e lesões

Enfermagem obstétrica

Revisão

\section{RESUMEN}

Este estudio tuvo como objetivo analizar las grietas del pezón causadas por el amamantamiento bajo el enfoque dermatológico. Se realizaron dos revisiones integradoras de la literatura, una relacionada con definiciones, clasificaciones y métodos de evaluación de las lesiones en el pezón y otra sobre los estudios de validación relacionadas a esas temáticas. En la primera se incluyeron 20 artículos y sólo un tercio de los estudios definió el trauma del pezón, más de la mitad no definió las lesiones del pezón reportadas y cada autor demostró una forma particular de evaluación de las lesiones, sin consenso. En la segunda revisión, no se encontró ningún estudio de validación y algoritmo relacionado con lesiones en el pezón causadas por la lactancia materna. Este hecho demuestra que las lesiones del pezón mencionadas en la primera revisión no pasaron por los estudios de validación, explicando las inconsistencias identificadas en relación a los métodos de evaluación, definición y clasificación de lesiones en el pezón.

\section{DESCRIPTORES}

Lactancia materna

Pezones

Heridas y traumatismos

Enfermería obstétrica

Revisión

Review "Extracted from the Master thesis entitled "Injuries resulted from breastfeeding process from the perspective of elementary skin lesions", Federal University
of Sao Paulo; 2012. ' Masters' in Nursing, Federal University of Sao Paulo, Sao Paulo, SP, Brazil. marina.possato@bol.com.br ${ }^{2}$ Associate professor,
Paulista School of Nursing, Federal University of Sao Paulo, Sao Paulo, SP, Brazil. ${ }^{3}$ PhD in Nursing, Federal University of Sao Paulo, Sao Paulo, SP, Brazil.
${ }^{4}$ Associate professor, Paulista School of Nursing, Federal University of Sao Paulo, Sao Paulo, SP, Brazil.

$\begin{aligned} \text { Rev Esc Enferm USP } & \text { Received: 07/29/2013 } \\ \text { 2014; 48(2):340-50 } & \text { Approved: 01/15/2014 } \\ \text { www.ee.usp.br/reeusp/ } & \text { Português / Inglês }\end{aligned}$




\section{INTRODUCTION}

Nipple trauma is a common cause for the abandonment of breastfeeding, by causing pain and discomfort to postpartum women. It is estimated that between 80 and $96 \%$ of women experience some degree of pain in the first week after labor ${ }^{(1-3)}$. Among the associated factors identified in researches, we highlight primiparity, the absence of the partner, engorged and turgid breasts conditions, protruding and/or malformed and depigmented nipples, inadequate latch and positioning of the neonate ${ }^{(4-5)}$.

In the literature, different forms of definition, classification and evaluation are observed for nipple trauma. However, a dermatological approach to this injuries is still missing. For some scholars in dermatology ${ }^{(6)}$, knowing and understanding what are the injuries, conducting an assessment, understanding the causes and risk factors for their development allow the entire health team to implement effective prevention and treatment actions.

Even though it is not possible to prevent the occurrence of an injury, it is essential to understand the interventions that accelerate the healing process, reducing the risk of harm and complications. In this sense, the recognition and description of nipple trauma, as well as the use of an appropriate assessment instrument, either a scale or a score, need to be well defined, so that the diagnosis of injuries is effective and enable an appropriate intervention.

Given the above, the following questions arose: What are the existing definitions on nipple trauma? How are the injuries classified and assessed? Is there a consensus among authors about these issues? If so, is there validation studies?

Thus, this study aimed to analyze nipple trauma under a dermatological approach. To this end, two specific objectives were proposed: to analyze the publications available in the literature about definitions, classifications and methods for evaluation of nipple trauma and analyze validation studies related to nipple injuries from breastfeeding practice.

\section{METHOD}

The integrative literature review was used as a methodological framework; the method allows simultaneous inclusion of quasi-experimental and experimental research, theoretical and empirical literature, providing a rich sample of studies and contributing to a more complete understanding of the topic of interest ${ }^{(7)}$.

For the development of this research, we conducted two integrative reviews: the first, called integrative review one (IR-1) and the second, integrative review two (IR-2), adopting six steps of development for each, such as: formulation of research question, selection of researches to compose the sample and definition of inclusion and exclusion criteria for the studies, definition of the information to be extracted from studies or data collection, evaluation or analysis of the included studies, interpretation of results and presentation of the review. To guide the IR-1, we formulated the following research question: What are the definitions, classifications and assessments of nipple injuries from breastfeeding? For IR-2: Are there validation studies of nipple injuries from breastfeeding?

The search was conducted in Medline (Medical Literature Online), Lilacs (Literature Latin American and Caribbean Health Sciences), PMC (PubMed Central), EMBASE (Excerpta Medica Database) and SciVerse Scopus, between January 2010 and October 2012. Initially, no date or language restriction was used. In IR-1, the following terms and/or words were used, as described in the data of Chart 1.

Chart 1 - Words and/or terms used in IR-1 - Sao Paulo, 2013

\begin{tabular}{|c|c|}
\hline Database & Terms or words \\
\hline \multirow{3}{*}{ MEDLINE } & 1. nipples [word] and sore [word] \\
\hline & 2. nipples [word] and trauma [word] \\
\hline & 3. nipples [word] and pain [word] \\
\hline \multirow{4}{*}{$\begin{array}{l}\text { PUBMED } \\
\text { Central }\end{array}$} & 1. nipples/injuries [mesh term] \\
\hline & 2. nipples $[$ mesh term] and pain $[$ mesh term $]$ \\
\hline & 3. nipples [mesh term] and sore [word] \\
\hline & $\begin{array}{l}\text { 4. nipples/injuries [mesh term] and (evaluation or } \\
\text { classification or signs and symptoms [unitermo } \\
\text { mesh] or treatment outcome [mesh term]) }\end{array}$ \\
\hline \multirow{3}{*}{ LILACS } & 1. mamilos [word] and dor [word] \\
\hline & 2. mamilos [word] and lesões [word] \\
\hline & 3. mamilos [word] and trauma [word] \\
\hline \multirow[t]{2}{*}{ EMBASE } & $\begin{array}{l}\text { 1. nipples [word] and pain [word] and breast feed- } \\
\text { ing [term] }\end{array}$ \\
\hline & 2. nipples/injuries [term] \\
\hline \multirow[t]{2}{*}{ SciVerse Scopus } & $\begin{array}{l}\text { 1. nipples [term/expanded] and pain [term/expanded] } \\
\text { and breast feeding [term/expanded] }\end{array}$ \\
\hline & 2. nipples/injuries [term/expanded] \\
\hline
\end{tabular}

In IR-2, the following words and/or terms were used as described in Chart 2.

Chart 2 - Words and/or terms used in IR-2 - Sao Paulo, 2013

\begin{tabular}{|c|c|}
\hline Database & Terms or words \\
\hline \multirow{4}{*}{ MEDLINE } & $\begin{array}{l}\text { 1. validation studies [publication type] and injuries } \\
\text { [descriptor of subject] and nipples [word] }\end{array}$ \\
\hline & $\begin{array}{l}\text { 2. reprodicibility of results [descriptor of subject] } \\
\text { and wounds [word] and nipples [word] }\end{array}$ \\
\hline & $\begin{array}{l}\text { 3. validation stwudies [publication type] and breast } \\
\text { feeding [word] }\end{array}$ \\
\hline & $\begin{array}{l}\text { 4. validation studies as topic [descriptor of subject] } \\
\text { and injuries [descriptor of subject] and nipples [word] }\end{array}$ \\
\hline \multirow{2}{*}{$\begin{array}{l}\text { PUBMED } \\
\text { Central }\end{array}$} & $\begin{array}{l}\text { 1. validation studies [publication type] or valida- } \\
\text { tion studies as Topic[mesh term] and questionnaires } \\
\text { [word] and lesions [word] and nipples [word] }\end{array}$ \\
\hline & $\begin{array}{l}\text { 2. validation studies [publication type] and lesions } \\
\text { [word] and nipples [word] }\end{array}$ \\
\hline \multirow{2}{*}{ LILACS } & $\begin{array}{l}\text { 1. feridas [word] and confiabilidade [word] and } \\
\text { mamilos }[\text { word] }\end{array}$ \\
\hline & $\begin{array}{l}\text { 2. reprodutibilidade dos testes [descritor de as- } \\
\text { sunto] and feridas [word] and mamilos [word] }\end{array}$ \\
\hline
\end{tabular}


Inclusion criteria for the IR-1 were: primary studies and up to date articles, which presented in the title or abstract of the publication one or more of the following words: trauma mamilar, lesão mamilar, fissura mamilar, dor mamilar, problemas na amamentação, dificuldades na amamentação, manejo clínico de problemas na amamentação ou avaliação da amamentação. We considered the translations: nipple trauma, nipple pain, sore nipple, wound nipple, fissures, cracked nipple, nipple damage, nipple injury, breastfeeding problems and breastfeeding management or measures, considering the term sore which can be translated as lesion or pain in Portuguese. The studies selected presented the topic nipple injuries, in its classification or assessment forms.

Inclusion criteria for IR-2 were: primary studies, available in the databases searched, which presented in the title or abstract of the publication one or more words: adaptação, validação, confiabilidade, reprodutibilidade, construção ou elaboração de escalas, lesões, ferida, mamilos, and its translations: adaptation, validation, reliability, development, lesions, wound e nipples. We attempted to select studies that presented the adaptation of a validated tool or the elaboration and validation of a new instrument related to the topic nipple injury from the breastfeeding. In both reviews, articles could be in English, Spanish, German and Portuguese languages.

Exclusion criteria common to the two reviews were: lack of abstract, unavailability to recover studies from countries in Latin America and the Caribbean and publications type letter, point of views or response from authors.

The reading, translation and data collection of the included studies were performed using a previously developed instrument. After these steps, ordering, summarization and analysis of the results in a descriptive manner was performed, highlighting the most significant studies.

\section{RESULTS}

\section{First integrative review (IR-1).}

We identified 1.375 publications in IR-1. Removing duplicates and applying the selection criteria, 63 references remained. Then, we proceeded to read the publications in full, resulting a final sample of 20 studies.

The selected studies were published between 1986 and 2013, with a predominance of 1997 . The research question began to be answered in 1986 in England by Professor and physician Barrie Herd, followed by Professor and nurse Vera Vinha, in Brazil, in 1987.

Regarding the languages in which the researches were published, we found six references in Portuguese and 14 in English, with the studies origin countries, Brazil, United States of America, Canada, Italy, Iran, Germany, Australia and England. There was a predominance of studies produced in Brazil, followed by the United States of America and Canada, suggesting a national interest in the study of the subject of nipple trauma. In only one study, it was not possible to identify the country of origin of the publication.

The 20 studies included in the sample contained the following designs: retrospective and prospective cohort (2), descriptive exploratory (1), case-control (2), randomized clinical trial - double blind (10) experimental (2) and experience report (3).

Among the journals in which the studies were published, there was a predominance of the Journal of Human Lactation and the Journal of Obstetrics, Gynecologic and Neonatal Nursing (three studies); both international and which receive Nursing manuscripts. From national origin, articles were published in the Revista da Escola de Enfermagem da USP, Acta Paulista de Enfermagem, Revista Brasileira de Enfermagem, Revista Femina (one study) and the Jornal de Pediatria (two studies).

Regarding the academic background of the first author, Nursing was prevalent by performing the majority of studies (12), followed by medical area (6) and Nutrition (1). In one of the studies, it was not possible to identify the academic background of the first author. The Breastfeeding remains an area of Nursing action and the topic nipple trauma is increasingly studied by nurses in Brazil, the United States of America and Canada.

In Chart 3 the studies included in the sample of IR1 are presented and the information presented on its definitions, classifications and assessment methods of nipple trauma.

Chart 3 - Included studies in the sample and data presented on the nipple trauma - Sao Paulo, 2013

\begin{tabular}{|c|c|c|c|c|}
\hline No & Included studies & Definition & Classification & Assessment method \\
\hline E1 & $\begin{array}{l}\text { Chaves MEA, Araújo AR, } \\
\text { Santos SF, Pinotti M, Oliveira } \\
\text { LS. LED phototherapy improves } \\
\text { healing of nipple trauma: a pilot } \\
\text { study. Photomedicine and Laser } \\
\text { Surgery. } 2012 ; 30(3): 172-78 .^{(8)}\end{array}$ & $\begin{array}{l}\text { Lesions characterized by disrup- } \\
\text { tion of the skin in the nipple- } \\
\text { areola region. }\end{array}$ & $\begin{array}{l}\text { Abrasion: are excoriation of } \\
\text { the skin, occurs exposing a } \\
\text { portion of the dermis. } \\
\text { Cracked skin: superficial skin } \\
\text { lesions with involvement of } \\
\text { the epidermis. } \\
\text { Fissure: slit-like lesion, with } \\
\text { involvement to the upper } \\
\text { dermis. }\end{array}$ & $\begin{array}{l}\text { Clinical examination to assess the } \\
\text { presence of nipple trauma and use } \\
\text { of photographic image enlarged } \\
\text { to calculate the area damaged by } \\
\text { planimetry. }\end{array}$ \\
\hline
\end{tabular}




\begin{tabular}{|c|c|c|c|c|}
\hline No & Included studies & Definition & Classification & Assessment method \\
\hline E2 & $\begin{array}{l}\text { Abou-Dakn M, Fluhr JW, } \\
\text { Gensch M, Wöckel A Positive } \\
\text { effect of HPA lanolin versus } \\
\text { expressed breastmilk on painful } \\
\text { and damaged nipples during lac- } \\
\text { tation. Skin Pharmacol Physiol. } \\
2011 ; 24(1): 27-35 .^{(9)}\end{array}$ & $\begin{array}{l}\text { Macroscopically detectable skin } \\
\text { lesions. }\end{array}$ & $\begin{array}{l}\text { Fissures, ulceration and ero- } \\
\text { sion without reporting concept } \\
\text { of injury. }\end{array}$ & $\begin{array}{l}\text { Nipple trauma score (NTS): vali- } \\
\text { dated by interobserver agreement } \\
\text { index of } 0.88 \text { in the Goodman's } \\
\text { gamma test. } \\
\text { 0- Nipple with no visible changes } \\
\text { in the microscopic skin. } \\
\text { 1-Presence of erythema or edema, } \\
\text { or a combination of both. } \\
\text { 2-Surface harm with or without } \\
\text { crusting in smaller area of } 25 \% \text { of } \\
\text { the surface of the nipple. } \\
3 \text { - Surface harm with or without } \\
\text { crusting in greater area of } 25 \% \text { of } \\
\text { the surface of the nipple. } \\
4 \text { Partial-thickness injury with or } \\
\text { without crusting less than } 25 \% \text { of } \\
\text { the area of the nipple surface. } \\
\text { 5-Partial-thickness injury with } \\
\text { or without crust formation in } \\
\text { an area greater than } 25 \% \text { of the } \\
\text { nipple area. }\end{array}$ \\
\hline E3 & $\begin{array}{l}\text { Coca KP, Gamba MA, Silva } \\
\text { RS, Abrão ACFV. Fatores as- } \\
\text { sociados ao trauma mamilar na } \\
\text { maternidade. Jornal de Pediatria. } \\
2009 ; 85(4): 341-5 .^{(4)}\end{array}$ & $\begin{array}{l}\text { Any presence of injury or patho- } \\
\text { logical change in the skin. }\end{array}$ & $\begin{array}{l}\text { Fissures, excoriation, erosions, } \\
\text { ecchymosis, marks and blisters, } \\
\text { no concept of the lesions. }\end{array}$ & $\begin{array}{l}\text { Clinical examination using a magni- } \\
\text { fying glass to evaluate the presence } \\
\text { of nipple trauma. }\end{array}$ \\
\hline E4 & $\begin{array}{l}\text { Coca KP, Gamba MA, Silva RS, } \\
\text { Abrão ACFV. A posição de ama- } \\
\text { mentar determina o aparecimen- } \\
\text { to do trauma mamilar? Revista } \\
\text { da Escola de enfermagem da } \\
\text { USP. 2009; 43(2):446-52. }\end{array}$ & $\begin{array}{l}\text { Solution of continuity of the skin } \\
\text { in the nipple-areola region. }\end{array}$ & $\begin{array}{l}\text { Fissures, excoriation, ero- } \\
\text { sions, vesicles and tear, no } \\
\text { report of concept. }\end{array}$ & $\begin{array}{l}\text { Clinical examination using a } \\
\text { magnifying glass to evaluate the } \\
\text { presence of nipple trauma. }\end{array}$ \\
\hline E6 & $\begin{array}{l}\text { Melli MS, Rashidi MR, Nok- } \\
\text { hoodchi A, Tagavi S, Farzadi } \\
\text { L, Sadaghat K, Tahmasebi Z, } \\
\text { Sheshvan MK. A randomized } \\
\text { trial of peppermint gel, lanolin } \\
\text { ointment, and placebo gel to pre- } \\
\text { vent nipple crack in primiparous } \\
\text { breastfeeding women. Med Sci } \\
\text { Monit. 2007; 13(9):406-11. }\end{array}$ & $\begin{array}{l}\text { Presence of lesions in the nipple- } \\
\text { areola region. }\end{array}$ & $\begin{array}{l}\text { Mild nipple damage: } 1-2 \mathrm{~mm} \text {. } \\
\text { Moderate nipple damage: } \\
3-9 \mathrm{~mm} \text {. Severe nipple dam- } \\
\text { age, with or without yellow } \\
\text { color visible nipple: greater } \\
\text { than } 10 \mathrm{~mm} \text {. }\end{array}$ & $\begin{array}{l}\text { Clinical examination and measure- } \\
\text { ment of cracked skin injury width } \\
\text { in millimeters. }\end{array}$ \\
\hline E7 & $\begin{array}{l}\text { Shimoda GT, Silva IA, Santos } \\
\text { JLF. Características, frequência } \\
\text { e fatores presentes na ocorrência } \\
\text { de lesão de mamilos em nu- } \\
\text { trizes. Rev Bras Enferm. } 2005 \text {; } \\
\text { 58(5):529-34. }{ }^{(12)}\end{array}$ & Not reported. & Not reported. & $\begin{array}{l}\text { Clinical examination to assess the } \\
\text { presence of nipple trauma. }\end{array}$ \\
\hline E8 & $\begin{array}{l}\text { Weigert EML, Giugliani E RJ, } \\
\text { França MCT, Oliveira LD, } \\
\text { Bonilha A, Espírito Santo LC, } \\
\text { Köhler CVF. Influência da } \\
\text { técnica de amamentação nas } \\
\text { frequências de aleitamento } \\
\text { materno exclusivo e lesões } \\
\text { mamilares no primeiro mês } \\
\text { de lactação. J Pediatr. 2005; } \\
\text { 81(4):310-6. }{ }^{(13)}\end{array}$ & Not reported. & $\begin{array}{l}\text { Fissures, blister, ecchymosis } \\
\text { and marks, no report of inju- } \\
\text { ries of the concept. }\end{array}$ & $\begin{array}{l}\text { Clinical examination to assess the } \\
\text { presence of nipple injury. }\end{array}$ \\
\hline E9 & $\begin{array}{l}\text { Dodd V, Chalmers C. Comparing } \\
\text { the use of hydrogel dressings to } \\
\text { lanolin ointment with lactating } \\
\text { mothers. J Obstet Gynecol Neona- } \\
\text { tal Nurs. 2003;32(4):486-94. } .^{(14)}\end{array}$ & Not reported. & Not reported. & $\begin{array}{l}\text { Phone call and evaluation as re- } \\
\text { sponse of participants. }\end{array}$ \\
\hline
\end{tabular}




\begin{tabular}{|c|c|c|c|c|}
\hline No & Included studies & Definition & Classification & Assessment method \\
\hline E10 & $\begin{array}{l}\text { Livingstone V, Stringer LJ. The } \\
\text { treatment of staphylococcus } \\
\text { infected sore nipples: a random- } \\
\text { ized comparative study. J Hum } \\
\text { Lact.1999; 15(3):241-46. }{ }^{(15)}\end{array}$ & $\begin{array}{l}\text { When there is evidence of dis- } \\
\text { ruption in skin integrity. }\end{array}$ & $\begin{array}{l}\text { Cracked skin, fissures and ul- } \\
\text { ceration, no report of concept. }\end{array}$ & $\begin{array}{l}\text { Scale 1-3 points: not reported the } \\
\text { result of parametric test. } 1 \text { - No } \\
\text { pain, intact skin surface. } 2 \text {-Per- } \\
\text { sistent pain, the injured surface } \\
\text { with no signs of healing skin. } \\
\text { 3-Persistence of pain, the injured } \\
\text { skin surface with greater extent } \\
\text { with purulent exudate. }\end{array}$ \\
\hline E11 & $\begin{array}{l}\text { Centuori S, Burmaz T, Ronfani } \\
\text { L, Fragiacomo M, Quintero S, } \\
\text { Pavan C, Davanzo R, Cattaneo } \\
\text { A. Nipple care, sore nipples, } \\
\text { and breastfeeding: a randomized } \\
\text { trial. J Hum Lact. 1999; 15(2): } \\
\text { 125-30. }{ }^{(16)}\end{array}$ & $\begin{array}{l}\text { Presence of nipple or breast tis- } \\
\text { sue lesions. }\end{array}$ & $\begin{array}{l}\text { Erythema, edema, vesicles } \\
\text { and fissures no report of } \\
\text { concept. }\end{array}$ & $\begin{array}{l}\text { Clinical examination to assess the } \\
\text { presence of nipple injury. }\end{array}$ \\
\hline E13 & $\begin{array}{l}\text { Lavergne NA. Does application } \\
\text { of tea bags to sore nipples while } \\
\text { breastfeeding provide effective } \\
\text { relief? J Obstet Gynecol Neona- } \\
\text { tal Nurs. 1997; 26(1):53-8.(18) }\end{array}$ & Not reported. & Not reported. & $\begin{array}{l}\text { Phone call and evaluation as } \\
\text { response of participants on the } \\
\text { conditions of the nipple skin. }\end{array}$ \\
\hline E14 & $\begin{array}{l}\text { Duffy EP, Percival P, Ker- } \\
\text { shaw E. Positive effects of } \\
\text { an antenatal group teaching } \\
\text { session on postnatal nipple } \\
\text { pain, nipple trauma and breast } \\
\text { feeding rates. Midwifery. } \\
\text { 1997; 13(4):189-96. }\end{array}$ & Not reported. & Not reported. & $\begin{array}{l}\text { Nipple Trauma Index (NTI) con- } \\
\text { sisted of three parts, with a score of } \\
\text { zero to } 34 \text {, the highest score being } \\
\text { the lowest nipple trauma. It was } \\
\text { reported the result of parametric } \\
\text { test. Part 1: provides information } \\
\text { on the condition of the nipple. Part } \\
2 \text { : provides data on the nipple se- } \\
\text { cretion. Part } 3 \text { : provides evaluation } \\
\text { of the woman over her nipples. }\end{array}$ \\
\hline E15 & $\begin{array}{l}\text { Cable B; Stewart M; Davis J Mt. } \\
\text { Nipple wound care: a new ap- } \\
\text { proach to an old problem. J Hum } \\
\text { Lact. } 1997 ; 13(4): 313-8 .^{(20)}\end{array}$ & Not reported. & Not reported. & $\begin{array}{l}\text { Location: the nipple-areolar junc- } \\
\text { tion on the side or end of the nipple } \\
\text { or the areola as a clock hours (eg: } \\
12 \text { hours). Depth of the affected } \\
\text { tissue: tissue involvement. Lesion } \\
\text { size: length and width using a } \\
\text { plastic instrument in millimeters } \\
\text { or centimeters. Visible features: } \\
\text { evaluated by redness, exudate } \\
\text { (color, type and quantity), edema, } \\
\text { epithelialization, and conditions of } \\
\text { the skin around the lesion. Not vis- } \\
\text { ible characteristics: odor and pain } \\
\text { assessment. }\end{array}$ \\
\hline E16 & $\begin{array}{l}\text { Ziemer MM, Cooper DM, Pi- } \\
\text { geon JG. Evaluation of a dress- } \\
\text { ing to reduce nipple pain and } \\
\text { improve nipple skin condition in } \\
\text { breastfeeding women. Nurs Res. } \\
\text { 1995; } 44(6): 347-51 . .^{(21)}\end{array}$ & Not reported. & $\begin{array}{l}\text { Edema, erythema, blister, } \\
\text { white, yellow or dark marks, } \\
\text { peeling, ecchymosis, crusting } \\
\text { and fissures, no report of } \\
\text { concept. }\end{array}$ & $\begin{array}{l}\text { Lesions were evaluated by } \\
\text { enlarged photographic image. For } \\
\text { the evaluation of crusts was used } \\
\text { to calculate area by planimetry. } \\
\text { For erythema and fissures, 4-point } \\
\text { scale: zero-none, } 1 \text { - mild, } 2 \text { - } \\
\text { moderate and } 3 \text {-severe. For other } \\
\text { types of injury was evaluated by } \\
\text { clinical examination of its presence } \\
\text { or absence. }\end{array}$ \\
\hline E17 & $\begin{array}{l}\text { Ziemer MM, Pigeon JG. Skin } \\
\text { changes and pain in the nipple } \\
\text { during the } 1 \text { st week of lactation. } \\
\text { J Obstet Gynecol Neonatal Nurs. } \\
1993 ; 22(3): 247-56 .^{(22)}\end{array}$ & Not reported. & $\begin{array}{l}\text { Erythema, edema, fissures, } \\
\text { blister, inflamed areas, crust- } \\
\text { ing, peeling, ecchymosis, } \\
\text { white, yellow or dark marks, } \\
\text { no report of injuries concept. }\end{array}$ & $\begin{array}{l}\text { Lesions were evaluated by en- } \\
\text { larged photographic image. }\end{array}$ \\
\hline
\end{tabular}

Livingstone V, Stringer LJ. The ized comparative study. J Hum trial. J Hum Lact. 1999; 15(2) Brent N, Rudy SJ, Redd B Rudy TE, Roth LA. Sore nipples clinical trial of wound dressing care Arch Lavergne NA. Does application ief? J Obstet Gynecol Neona-

Duffy EP, Percival P, KerE. Positive effects of session on postnatal nipple ain, nipple trauma and breast feeding rates. Midwifery.

. piple wound care. a new apimprove nipple skin condition in breastfeeding women. Nurs Res.
Scale 1-3 points: not reported the pain, intact skin surface. 2-Perpistent pain, the injured surface with greater extent with purulent exudate.

Clinical examination to assess the concept. 


\begin{tabular}{|c|c|c|c|c|}
\hline No & Included studies & Definition & Classification & Assessment method \\
\hline E18 & $\begin{array}{l}\text { Walker M, Driscoll JW. Sore } \\
\text { nipples: the new mother's nem- } \\
\text { esis. MCN Am J Matern Child } \\
\text { Nurs.1989;14(4):260-5. }{ }^{(23)}\end{array}$ & Not reported. & $\begin{array}{l}\text { Sensitive nipples: strong pink } \\
\text { color. Sore nipples: reddened } \\
\text { skin, with or without bruising } \\
\text { at the base of the nipple, } \\
\text { burning sensation or throb- } \\
\text { bing pain. Nipple with altered } \\
\text { integument: the presence of } \\
\text { abrasion, blister, cracked skin, } \\
\text { fissure and ecchymosis. }\end{array}$ & Not reported. \\
\hline E19 & $\begin{array}{l}\text { Vinha VHP, Pelá NTR, Shimo } \\
\text { AKK, Scochi CGS. Trauma } \\
\text { mamilar: proposta de tratamento. } \\
\text { Femina. } 1987 ; 15(5): 370-8 .^{(24)}\end{array}$ & Not reported. & $\begin{array}{l}\text { Adequate nipples: present- } \\
\text { ing complete and perfect } \\
\text { structure. Fissured nipples: } \\
\text { presenting linear, superficial } \\
\text { ulceration with involvement } \\
\text { of the dermis, located in the } \\
\text { nipple-areola junction or on } \\
\text { the surface of the nipple, } \\
\text { being: small: measuring up to } \\
3 \mathrm{~mm} \text {; average: measuring up } \\
\text { to } 5 \mathrm{~mm} \text { large: greater than } \\
5 \mathrm{~mm} \text {, bleeding can occur. } \\
\text { Excoriated nipples: skinned } \\
\text { surface or epidermis elevated. } \\
\text { Nipples eroded: present } \\
\text { surface wear. }\end{array}$ & Not reported. \\
\hline E20 & $\begin{array}{l}\text { Herd B, Feeney JG. Two } \\
\text { aerosol sprays in nipple } \\
\text { trauma. The Practitioner. 1986; } \\
\text { 230(1411):31-8. } .^{(25)}\end{array}$ & Not reported. & Not reported. & $\begin{array}{l}\text { Scale } 0-6 \text { points: not reported the } \\
\text { result of parametric test. } \\
\text { Zero - normal nipple, } 1 \text { - light } \\
\text { sensitivity with no visible signs } \\
\text { of injury; } 2 \text { - redness and warmth; } \\
\text { 3-bleeding; } 4 \text { - cracked skin; } 5 \\
\text { with abscess. }\end{array}$ \\
\hline
\end{tabular}

\section{Second integrative review (IR-2)}

In the IR-2, we identified 52 publications, but none was included, because it did not analyzed the researched topic. Most of the studies-related validation of scales or index on breastfeeding, as self-efficacy and confidence in breastfeeding, the risk of early weaning, breastfeeding assessment, evaluation of attachment during breastfeeding, evaluation of women on the support provided on breastfeeding, evaluation of oralmotor characteristics of preterm and validation of the diameter of the nipple and measures of tongue movement of the newborn.

One study ${ }^{(26)}$ from a reference used in the first step of this research indicated to a research that developed a score for assessing cracked skin nipple during breastfeeding, but this was not identified in databases or archives in the journals publication or by searching other countries.

\section{DISCUSSION}

\section{First integrative review (IR-1)}

This review sought to identify in the studies definition, classification and assessment of nipple trauma and discuss them from a dermatological perspective, more specifically, of elementary skin lesions.

\section{Definition of nipple trauma}

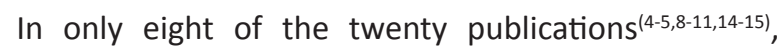
nipple trauma was defined; the concepts presented were similar in terms of disruption, lesion and injury to seven authors $^{(5,8-11,14-15)}$. One author ${ }^{(4)}$ presented a broader definition of nipple trauma, referring to the pathological change of the skin. Thus, nipple trauma is considered as injuries type ecchymosis, blisters and marks. For a researcher ${ }^{(27)}$, pathological skin changes are vascular lesions, changing in color, texture and shape of the skin. From the dermatological approach ${ }^{(28-30)}$, lesions refer to color, contents (liquid, solid) and thickness changes.

In assistance to women with nipple trauma, it is highlighted the existence of injury of erythema type, particularly in the early breastfeeding, often accompanied by increased sensitivity of the nipple-areola region or acute pain. It is suggested so that the nipple trauma is considered to be ruled by an alteration of the normal anatomy of the nipple skin, as the presence of a primary skin lesion caused by the change in color, thickness or liquid contents and not only as a solution of continuity in the skin.

\section{Classification of nipple trauma}

Studies of the sample described as nipple lesion: erythema, ecchymosis, white, yellow, or dark marks, bruising, edema, blister, vesicle, fissures, cracked skin, erosion, excoriation, 
ulceration, abrasion, crusting and peeling ${ }^{(4-5,8-9,13,15-17,21-24)}$. It was observed the presence of similarities and discrepancies in the nomenclature of these lesions in 12 of the 20 publication of the sample. More than half of the studies (16) did not set the nipple injuries and there was disagreement as to the form of description of nipple damage and impairment of the injured tissue.

Elementary primary skin lesions were cited as erythema, ecchymosis, bruising, vesicle and blister ${ }^{(4-5,13,16-17,21-23)}$. According to scholars ${ }^{(28-31)}$, the lesion type erythema may exist among nipple trauma, with agreement for the presence of an alteration of the normal color of the skin of the nipple to pink or red. In clinical practice, there is an area of hyperemia without solution of continuity of the skin. In this sense, how to identify this type of injury, when does the normal color of the nipple go from pink to black? How to identify a lesion of red color in black skin? For the classification of nipple trauma, would not be necessary, besides the color, the addition of other morphological features of the lesion? Certainly, because when performing the clinical examination in black skin the coloration accents to dark red or purplish, being essential to exclude the presence of some kind of water volume.

The injury type ecchymosis may exist within the nipple trauma. However, the way it is described in the literature ${ }^{(28-31)}$, it could reach more than half of the nipple area, since its diameter is presented on average from 1.5 to 2.0 $\mathrm{cm}^{(32)}$. In clinical practice, ecchymosis is characterized by dermatology, as difficult to be identified.

Regarding injury type bruising, there is agreement on the presence of a blood collection, with increased injury ${ }^{(28-30)}$. However, what would be its appearance on the nipple surface? Can this type of injury be considered nipple injury resulting from breastfeeding? In clinical practice, this injury is more difficult to observe during breastfeeding.

For a group of researchers ${ }^{(28-30,33)}$, the vesicle can be conceptualized as an elevated lesion with liquid content and changing the shape of the skin, it may be of physiological skin color, white, yellow or crimson. In clinical practice, this type of injury is frequently observed between the nipples.

Regarding blisters, the way it is described in the literature ${ }^{(28-31)}$, it would reach more than half of the nipple area. It is believed that the authors may have used the sample word blister as a generic term and that injury would be displayed as vesicle by the mother, and not a blister, which was neither measured, nor conceptualized.

Regarding elementary secondary skin lesions were cited edema, cracked skin, fissure, erosion, excoriation and ulceration ${ }^{(4-5,8-9,13,15-17,21-25)}$. According to research$\mathrm{es}^{(28-30)}$, edema type of injury is defined as the presence of change in skin, alteration of the consistency and color of the skin itself or pink. In clinical practice, it is observed distended area of the skin without solution of continuity, with alteration of thickness and hardened of physiological skin color or pinkish, sometimes brilliant. Edema can be considered a result of nipple trauma of breastfeeding because besides being characterized as an elementary skin lesion, it is referred by researchers in breastfeeding and observed in clinical practice. In some women, their appearance is secondary to erythema, suggesting a progression of trauma severity.

With regard to injury type fissure, there is the presence of differences and similarities regarding the conceptualization, shape, affected tissue, size and location, when comparing the sample and literature studies. Fissure was defined in the studies as linear ulceration ${ }^{(24)}$ and superficial lesion ${ }^{(27)}$. In a dermatological perspective, this is an elementary secondary skin lesion, but it is not an ulceration, because it does not reach deep tissue ${ }^{(28,30)}$. A reference in breastfeeding ${ }^{(31)}$ classifies fissure as an erosion of partial thickness, a solution of continuity in the skin involving the destruction of the epidermis to the lower layer of the dermis. However, the European Pressure Ulcer Advisory Panel and the National Pressure Ulcer Advisory Panel recommended that the term erosion of partial thickness should not be used to describe skin fissures, maceration or ulceration, because it is primarily a categorization developed for pressure ulcers ${ }^{(34)}$.

In five of the studies selected ${ }^{(9,24,27-29)}$, fissure was defined as a solution of continuity with linear tissue loss or cleft type. But with respect to the affected tissue, a researcher in breastfeeding ${ }^{(27)}$ claimed that in fissure, skin loss occurs; while to another research, the affected tissue may be epidermis and it may be the dermis ${ }^{(33)}$. Among others ${ }^{(8,24,28-29,31)}$, the tissues affected in fissure are the epidermis and dermis, the upper layer ${ }^{(8)}$ or even lower layer of the dermis ${ }^{(31)}$. It appears, therefore, that there is lack of consensus regarding the cutaneous involvement of fissure, if it only affects the epidermis or epidermis and dermis.

In clinical practice, different sizes of fissures may be observed, however, it is difficult to define, upon inspection, the depth of the affected tissue. How to identify the loss of the epidermis, or even in a part of the dermis in nipple fissures if the skin in the mammary papilla is approximately $0.5 \mathrm{~mm}$ thick ${ }^{(35)}$ ? Thus, the clinical examination, even with a magnifying glass, there may be difficulty in identifying the tissue involvement.

Regarding the size of the fissures, a publication mentions three sizes of injuries ${ }^{(24)}$. In clinical practice, measurement of the lesion in millimeters can facilitate their evaluation, since the depth is difficult to identify.

Other characteristics of injury may contribute to the diagnosis of the depth of nipples fissure, such as: the presence of bleeding, exudation, pus, crusts and even pain, because bleeding, crusting or pus can indicate the involvement of the dermis ${ }^{(36-37)}$. It is observed that $a$
Injuries resulted from breastfeeding: a new approach to a known problem Cervellini MP, Gamba MA, Coca KP, Abrão ACFV 
fissure starts by the involvement of superficial layers of the skin and in the maintenance of the causal factor or in the absence of adequate treatment, the lesion deepens, affecting other layers of the skin. Regarding the cracked skin mentioned in four studies ${ }^{(8,11,17,23)}$, it is believed that it had been used as synonymous of fissure, which is also found in clinical practice.

The erosion lesion type had its definition presented only by one study ${ }^{(24)}$, as a wear surface. In a dermatological approach, erosion is a solution of continuity in the skin, with involvement of the epidermis ${ }^{(28-29)}$. For excoriation lesion type, a similar definition was presented as erosion by the same study ${ }^{(24)}$, being excoriation a superficial skinned with involvement of the epidermis. It is noteworthy that the dermatological approach, the excoriation is a type of erosion caused by friction through itching ${ }^{(28-29)}$. In this sense, inadequate suction of the child could be considered a triggering friction excoriation?

No study has defined the type of ulceration lesions, however, it is known that this lesion is secondary or deep$\mathrm{er}^{(27-30)}$, it can affect the epidermis and dermis ${ }^{(27)}$ or epidermis, dermis, sometimes, subcutaneous tissue and deep tissue ${ }^{(28-29)}$. In clinical practice, it is understood that the nipple injury due to inadequate suction of the newborn during breastfeeding is superficial, occurring its aggravation from the loss of dermis. For a researcher ${ }^{(27)}$, this lesion is the result of prolonged trauma and untreated fissures.

Other nipple injuries cited, but not identified in dermatological glossaries were white, yellow or dark marks. Indeed, it is not nipple injuries, but dermatological elementary skin lesion of stain or blemish type ${ }^{(28-29)}$. One must consider, however, if the white mark described by the studies sample $e^{(5,13,21-22)}$ would not be a maceration and dark marks, a primary skin lesion of color change.

Two studies cited abrasion as a nipple injury, defining it as an excoriation of the skin with dermal exposure $^{(8)}$ and skin alteration ${ }^{(23)}$. However, abrasion is the process of wear (scrape or ulceration) of skin or mucous membranes by mechanical or chemical means ${ }^{(38)}$, being non-existent as a lesion, and inadequate acceptance as nipple injury. The excoriation caused by the abrasion is present in dermatological procedures such as dermabrasion or peeling ${ }^{(28-30)}$.

Three studies cited crust as nipple injury ${ }^{(17,21-22)}$, without defining it. In dermatology, the injured area which features a crust brings the clinical appearance of a lesion that is in the healing process, resulting in platelet aggregation and blood clotting which generated a rich fibrin cap and, later, with the dryness of this cap or clot, protects the injured area ${ }^{(36-37)}$. In this sense, the crust could not be considered a nipple injury, but their existence can be characterized as a process of physiological healing of an injury.

Three studies cited crust as nipple injury ${ }^{(17,21-22)}$, without defining it. For Dermatology, crust is a process resulting from allergy causing injuries crust type ${ }^{(28-30)}$. In clinical practice, crust is not understood as a nipple injury, being caused by allergic processes or frequent use of loath bath brush in the nipples.

Among the concepts presented for each lesion, due to the different expertise of specialists in dermatology and breastfeeding, the comparison was difficult and inaccurate, as it can be observed with respect to fissures, erosion and excoriation. In this sense, a new classification of nipple trauma needs to be proposed based on the experience of breastfeeding and dermatological approaches. Thus, it is suggested that the nipple injuries are classified into primary and secondary, being the difference between them, the appearance of a continuity solution of the skin.

\section{Assessment method of nipple trauma}

In 18 of the 20 publications of the sample were described different forms of evaluation of nipple trauma. Between resources and assessment methods, it was highlighted the use of measurement instruments (scales, indexes or scores), the measurement of the lesions, the clinical examination, the use of magnifiers glasses, using enlarged photographs and telephone calls.

With respect to the application of measurement instruments, seven publications used a previously developed instrument ${ }^{(9,15,17,19,21-22,25)}$; however, only one of the clinical studies $^{(9)}$ reported its validity by means of the interobserver agreement index.

In eight studies, it was conducted an evaluation of the presence of nipple injury by clinical examination $^{(4-5,8-13,16,21)}$; in three, with the use of magnifying glasses ${ }^{(4-5,10)}$; and in four enlarged high resolution photographs ${ }^{(8,17,21-22)}$. Currently, the use of photography is a fundamental tool in daily dermatological practice, and it can be used from simple record of lesions in dermatological examination to the illustration of a treatment outcome. However, it is necessary to have knowledge of the basics of photographic technique, including the available equipment, notions of digital technology and the establishment of a photographic routine that includes the standardization of photographs. This ensures the clinical likelihood and avoids losses by the inadequacy of photographic documentation ${ }^{(39)}$.

One study ${ }^{(40)}$ whose objective was to evaluate the correlation between dermatological diagnoses made by observation and digital images found through parametric tests that agreement with images was lower than the face to face agreement, noting that imaging cannot replace conventional medical consultation.

The clinical examination by direct inspection with magnifying glasses may be the best way to assess nipple trauma. Besides having low cost, it allows the diagnosis at the time of consultation. In the literature, there is no 
guide for evaluation of nipple clinical examination, thus the training of health professionals allows the identification of items that characterize the condition of the nipple at the consultation time.

In two studies ${ }^{(14,18)}$ phone calls were used to perform the assessment as the response of participants on the conditions of the nipple skin. It is understood that this method is based on the woman's answer to the lesion does not provide a reliable assessment, since the woman cannot get a good view of their nipple itself and she is not qualified to do so, which leads to the subjectivity of the data provided. However, this method of valuation can assist in monitoring this condition.

In six studies the measurement of the nipple trauma in different ways was carried out; in three, the extent of the lesions was measured with a measuring tape in millimeters $^{(11,17)}$ or centimeters ${ }^{(10)}$, in other three, the injured area was calculated by planimetry ${ }^{(8,21-22)}$.

One publication ${ }^{(20)}$ described some evaluation criteria: location, depth of the affected tissue, size, visible features (redness, swelling or epithelium) and not visible (pain, odor) of the lesion and appearance of the surrounding tissue. Although this research is from 1997, it brought a perspective at the nipple injury with the aid of Dermatology, considering important the detailed description of the injury to its treatment, adding that the same physiological principles happen in any injury.

For one author ${ }^{(41)}$, assessing an injury is describing it, in a way that the records are reliable to their clinical characteristics. This assessment should be performed based on the normal anatomy of the skin and tissue and in the physiology of the healing process by specifying its size, the type of tissue, the characteristics of the injured skin, the amount and characteristics of the exudate and signs of infection. For some researchers ${ }^{(6)}$, during the healing process, some apparent morphological features of the lesion may indicate its evolution or aggravation.

Anyway, it is essential to diagnose the type of lesion found by appropriate dermatological evaluation. The literature is still scarce to demonstrate how a physical examination with nipple assessment or even the nipple injury, making its assessment particular and defined by the accumulated knowledge of every healthcare professional.

This first integrative review revealed several gaps to be answered, such as: How does the nipple trauma could be defined? What injuries would be classified as nipple trauma? How could we assess a nipple trauma?

Among the nipple injuries cited, a concern about standardization and identification of trauma from the standpoint of elementary primary or secondary skin lesions was not observed. The lack of a dermatological approach in the understanding of nipple trauma results in discrepancies in the definitions, classification and evaluation, so that, in clinical practice, its diagnosis and treatment may be compromised.

\section{Second integrative review (IR-2)}

Validation studies are essential for clinical practice, as they enable the accuracy of the observed phenomena. Specifically with regard to assessment tools, their usefulness in dermatology have been recognized. In clinical practice, it guides the prevention, diagnosis and treatment of injuries. For scientific research, an assessment tool improves and fosters communication among professionals of the healthcare team, it also enables professionals to achieve their intended objectives and, consequently, to evaluate the effect of an intervention ${ }^{(6)}$.

This second review was performed to identify publications on validation studies related to definitions, classifications and assessment methods described in the IR-1. As no study has been found, we can state that the nipple trauma resulted from breastfeeding did not appear as an object of study, thus identifying a gap in this topic. This finding reveals that the definitions, classifications and assessment methods of nipple injuries in researches identified in the IR-1 have not gone through validation studies, explaining the inconsistencies identified.

\section{CONCLUSION}

There was no consensus between the definition, classification and assessment methods of nipple lesions in studies of the sample of IR-1. Similarly, in the IR-2, we noted that the content identified did not go through a validation process. The lack of a standardized algorithm for evaluating and classifying nipple trauma shows the need for the development and validation of a content that may define and classify nipple trauma, allowing specific and accurate assessment.

This fact can bring several clinical implications, since, while the bias persists, observing and evaluating a nipple trauma can lead to diverse and conflicting interpretations, because of the variety, nature, shape and location, beyond the perception of each professional, considering the difference of existing knowledge. Thus, the same skin lesion can be assessed differently, have different clinical records and conducts.

The definition and classification of nipple trauma, with dermatological lesions understanding, nipple tissue specificities and breastfeeding can provide health professionals a standardized common language, helping to advance knowledge of the injury, making specific treatment for a given injury and contributing to the education and processes of decision-making of professionals and students. This new classification will serve as a foundation for other clinical research involved with the scientific evidence of a treatment for nipple trauma, with protocols of preventative and treatment care and to the causative factor of each lesion development in nipple trauma.
Injuries resulted from breastfeeding: a new approach to a known problem Cervellini MP, Gamba MA, Coca KP, Abrão ACFV 


\section{REFERENCES}

1. Abrão ACFV, Coca KP, Pinelli FSG, Vieira E. Dificuldades no processo de aleitamento materno. In: Barros SMO. Enfermagem obstétrica e ginecológica: guia para a prática assistencial. 2a ed. São Paulo: Roca; 2009. p.332-70.

2. Teruya K, Bueno LGS, Serva V. Manejo da lactação. In: Rego JD. Aleitamento materno. 2a ed. São Paulo: Atheneu; 2009. p. 137-57.

3. The Joanna Briggs Institute. The management of nipple pain and/or trauma associated with breastfeeding. Aust Nurs J. 2009;17(2):32-5.

4. Coca KP, Gamba MA, Silva RS, Abrão ACFV. Fatores associados ao trauma mamilar na maternidade. J Pediatr. 2009;85(4):341-5.

5. Coca KP, Gamba MA, Silva RS, Abrão ACFV. Does breast feeding position influence the onset of nipple trauma? Rev Esc Enferm USP [Internet]. 2009 [cited 2013 Oct 21]; 43(2):44652. Available from: http://www.scielo.br/pdf/reeusp/v43n2/ en_a26v43n2.pdf

6. Santos VLCG, Azevedo MAJ, Silva TS, Carvalho VMJ, Carvalho VF. Adaptação transcultural do Pressure Ulcer Scale for Healing (PUSH), para a língua portuguesa. Rev Latino Am Enferm. 2005;13(3):305-13.

7. Mendes KDS, Silveira RCCP, Galvão CM. Revisão integrativa: método de pesquisa para a incorporação de evidências na saúde e na enfermagem. Texto Contexto Enferm. 2008; 17(4):758-64.

8. Chaves MEA, Araújo AR, Santos SF, Pinotti M, Oliveira LS. LED phototherapy improves healing of nipple trauma: a pilot study. Photomed Laser Surg. 2012;30(3):172-8.

9. Abou-Dakn M, Fluhr JW, Gensch M, Wöckel A Positive effect of HPA lanolin versus expressed breastmilk on painful and damaged nipples during lactation. Skin Pharmacol Physiol. 2011;24(1):27-35.

10. Coca KP, Abrão ACFV. Avaliação do efeito da lanolina na cicatrização dos traumas mamilares. Acta Paul Enferm. 2008;21(1):11-6.

11. Melli MS, Rashidi MR, Nokhoodchi A, Tagavi S, Farzadi L, Sadaghat $K$, et al. A randomized trial of peppermint gel, lanolin ointment, and placebo gel to prevent nipple crack in primiparous breastfeeding women. Med Sci Monit. 2007;13(9):406-11.

12. Shimoda GT, Silva IA, Santos JLF. Características, frequência e fatores presentes na ocorrência de lesão de mamilos em nutrizes. Rev Bras Enferm. 2005;58(5):529-34.
13. Weigert EML, Giugliani ERJ, França MCT, Oliveira LD, Bonilha A, Espírito Santo LC, et al. Influência da técnica de amamentação nas frequências de aleitamento materno exclusivo e lesões mamilares no primeiro mês de lactação. J Pediatr. 2005;81(4):310-6.

14. Dodd V, Chalmers C. Comparing the use of hydrogel dressings to lanolin ointment with lactating mothers. J Obstet Gynecol Neonatal Nurs. 2003;32(4):486-94.

15. Livingstone V, Stringer LJ. The treatment of staphylococcus infected sore nipples: a randomized comparative study. J Hum Lact.1999;15(3):241-6.

16. Centuori S, Burmaz T, Ronfani L, Fragiacomo M, Quintero S, Pavan C, et al. Nipple care, sore nipples, and breastfeeding: a randomized trial. J Hum Lact. 1999;15(2):125-30.

17. Brent N, Rudy SJ, Redd B, Rudy TE, Roth LA. Sore nipples in breast-feeding women: a clinical trial of wound dressing vs conventional care. Arch Pediatr Adolesc Med. 1998; 152(11):1077-82.

18. Lavergne NA. Does application of tea bags to sore nipples while breastfeeding provide effective relief? J Obstet Gynecol Neonatal Nurs. 1997;26(1):53-8.

19. Duffy EP, Percival P, Kershaw E. Positive effects of an antenatal group teaching session on postnatal nipple pain, nipple trauma and breast feeding rates. Midwifery. 1997; 13(4):189-96.

20. Cable B, Stewart M, Davis J. Nipple wound care: a new approach to an old problem. J Hum Lact. 1997;13(4):313-8.

21. Ziemer MM, Cooper DM, Pigeon JG. Evaluation of a dressing to reduce nipple pain and improve nipple skin condition in breastfeeding women. Nurs Res. 1995;44(6):347-51.

22. Ziemer MM, Pigeon JG. Skin changes and pain in the nipple during the 1st week of lactation. J Obstet Gynecol Neonatal Nurs. 1993;22(3):247-56.

23. Walker M, Driscoll JW. Sore nipples: the new mother's nemesis. MCN Am J Matern Child Nurs. 1989;14(4):260-5.

24. Vinha VHP, Pelá NTR, Shimo AKK, Scochi CGS. Trauma mamilar: proposta de tratamento. Femina. 1987;15(5):370-8.

25. Herd B, Feeney JG. Two aerosol sprays in nipple trauma. Practitioner. 1986; 230(1411):31-8.

26. Wockel A, Schumann M, Abou-Dakn M. Development of a wound score for the evaluation of cracked nipples during lactation. Arch Gyn Obst. 2004;17 Suppl 1:270. 
27. Biancuzzo M. Sore nipples: prevention and problem-solving. Herndon: WMC Worldwide; 2000.

28. Sampaio SAP, Rivitti EA. Dermatologia. 3a ed. São Paulo: Artes Médicas; 2008.

29. Habif TP. Dermatologia clínica: guia colorido para diagnóstico e tratamento. 5ạ ed. São Paulo: Campus/Elsevier; 2012.

30. Petri V. Dermatologia prática. Rio de Janeiro: GuanabaraKoogan; 2009.

31. Mohrbacher N. Breastfeeding answers made simple: a guide for helping mothers. Amarillo, TX: Hale; 2010.

32. McClellan HL, Sakalidis VS, Hepworth AR, Hartmann PE, Guedes DT. Validation of a nipple diameter and tongue movement measurements with B-mode ultrasound during breastfeeding. Ultrasound Med Biol. 2010;36(11):1797-807.

33. Vinha VHP. Projeto Aleitamento Materno: autocuidado com a mama puerperal. São Paulo: Sarvier; 1994.

34. European Pressure Ulcer Advisory Panel and National Pressure Ulcer Advisory Panel. Prevention and treatment of pressure ulcers: quick reference guide. Washington: National Pressure Ulcer Advisory Panel; 2009.
35. Graaff V. Anatomia humana. 6a ed. Barueri: Manole; 2003.

36. Mendonça RJ, Coutinho-Netto J. Aspectos celulares da cicatrização. An Bras Dermatol. 2009; Jul.; 84(3):257-65.

37. Robbins L, Stanley L. Patologia básica. 8a ed. Rio de Janeiro: Elsevier; 2008.

38. Houaiss A. Dicionário Houaiss da Língua Portuguesa. Rio de Janeiro: Objetiva; 2009.

39. Pinheiro MVB. A fotografia na cirurgia dermatológica e na cosmiatria: parte I. Surg Cosmet Dermatol. 2013;5(2):101-8.

40. D’Elia PB, Fisher PD, Bordin R, Harzheim E, Ramos MC. Concordância entre diagnósticos dermatológicos feitos presencialmente e por imagens digitais. An Bras Dermatol. 2007;82(6):521-7.

41. Dealey C, Cameron J. Wound management. Oxford: WileyBlackwell; 2008. 